\title{
Mechanisms of Brain Damage in Twins
}

\author{
MARGARET G. NORMAN
}

\begin{abstract}
SUMMARY: The brains of 18 twins dying in the perinatal period showed a variety of lesions. Eleven had subependymal cell plate hemorrhage which had ruptured into the lateral ventricles in five. Five had periventricular damage. Three had anoxic neuronal damage. One acardiac monster had bilateral cerebral infarction. One pair had unequal sized brains, probably due to unequal intrauterine nutrition. Twins have a high perinatal mortality and morbidity; as well, intrauterine events may alter brain growth and development in each twin unequally, so they are an imperfect model to study the effect of genes and environment on intelligence.
\end{abstract}

RÉSUMÉ: Les cerveaux de 18 jumeaux décédés pendant la période périnatale ont montré une variété de lésions. Chez 11 patients il existait une hémorragie de la plaque cellulaire sous-épendymale, qui s'était rupturée dans le ventricule latéral chez 5 d'entre eux. Cinq patients également montraient des lésions périventriculaires alors que trois autres avaient des lésions neuronales anoxiques. Un monstre acardiaque avait un infarctus cérébal bilatéral. Chez une paire de jumeaux les cerveaux étaient de grosseur inégale, probablement à cause d'une nutrition intra-utérine inégale. On sait que les jumeaux ont une mortalité et une morbidité périnatale élevée; cependant des évènements intra-utérins peuvent changer la croissance et le développement de façon différente chez chacun des jumeaux. Ceux-ci constituent donc un modele imparfait pour l'étude des gènes et de l'environnement sur l'intelligence.

From the Department of Pathology, Vancouver General Hospital and University of British Columbia.

Reprint requests to: Dr. M.G. Norman, Children's Hospital, 4480 Oak Street, Vancouver, B.C. V6H 3 V4 Canada.

\section{INTRODUCTION \\ Although it has been known for} some time that twins constitute a disproportionate number of those with the diagnosis of "cerebral palsy", and are particularly prone to develop "multicystic encephalomalacia of infancy", there has been no systematic review of the neuropathological lesions found in twins. This series describes lesions in eighteen twins who died in the perinatal period. The lesions observed can be divided into five main groups. The first two are lesions of prematurity - subependymal cell plate hemorrhage (SECPH) and periventricular infarction (PVI). Anoxic neuronal damage occurring secondary to perinatal asphyxia is the third. The fourth group consist of destructive lesions or interference with neuronal migration associated with cerebral ischemia resulting from inequalities of perfusion between twins with monochorionic placentas containing anastamoses (Fig. 1); similar destructive lesions also occur in singletons and dichorionic twins secondary to placental and cord problems. The last, unique to twins, is difference in the size of the brains of a twin pair. Malformations, which occur in greater incidence in twins, anencephaly and perinatal infections are excluded from this report.

\section{MATERIAL AND METHOD}

The necropsies on all stillborns and neonates at Vancouver General Hospital (VGH) between January 1 December 31,1980 were reviewed. The VGH is a primary and tertiary care and teaching hospital, with a high risk pregnancy unit, intensive care nursery, embryopathology and pediatric pathology services, to which both living and dead infants are referred from Vancouver and the rest of the province. There was a total of 271 fetal and neonatal autopsies. 141 were of fetuses and embryos of less than 20 weeks gestation, including those in which gestation had been terminated because of antenatal diagnosis of disease. Six pairs of twins were present in this group, but were so badly macerated that, except for the diagnosis of anencephaly in one of a pair of diamniotic, dichorionic, male twins of unknown zygosity, the brains were not suitable for examination. In the remaining 130 autopsies of infants greater than 20 weeks gestation, 26 twins were present. Eight were stillborn and too macerated for examination. The remaining 18 , all of whom were premature, are the subject of this report.

\section{RESULTS}

In eight cases only one twin of the pair was autopsied (Table, cases 1 - 8). Only one infant (case 3) was without a brain lesion. Cases 5, 6, and 8 had $\mathrm{SECPH}$; these infants died of prematurity or complications thereof. Cases 1, 2, 4, 7 had SECPH with rupture into the lateral ventricles. Cases 1 , $4,6,8$ had damage in the centrum semiovale, case 4 (Fig. 2) a cavitated infarct, case 6 marked gliosis, and case 8 a macrophage reaction. Cases 7 and 8 had anoxic neuronal damage. Case 1 had small cerebellar hemorrhages which were probably of no significance; case 4 showed loss of cerebellar cortical neurones in the banks of adjacent folia. In summary, four (cases $4,6,7,8)$ showed severe cerebral damage, which was not the cause of death, the infants dying of complications of their prematurity.

The remaining autopsied cases consisted of five pairs of twins (Table, Cases 9-13). Pair 9A and B of 20-22 weeks gestation who survived for only a few minutes had SECPH confined to the germinal eminence. A twin pair of 27 week gestation (Cases $12 \mathrm{~A}, \mathrm{~B}$ ) both had SECPH. One died the day after birth and had extension of hemorrhage into the ventricles. This was the only infant to die of the cerebral lesion. The other twin (12 B) lived 17 days and had 
CLINICAL AND PATHOLOGICAL FINDINGS

\begin{tabular}{|c|c|c|c|c|c|c|c|c|c|}
\hline & 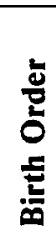 & 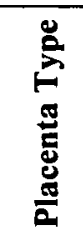 & 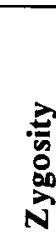 & 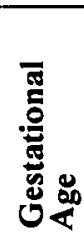 & . & $\stackrel{x}{\varpi}$ & $\stackrel{\mathscr{0}}{\mathfrak{0}}$ & 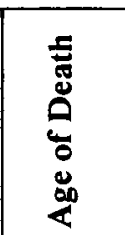 & Pathological Findings \\
\hline 1 & B & DM & $\mathbf{M}$ & 27 & $? \mathrm{~d}$ & $\mathrm{~F}$ & + & $2-1 / 2 d$ & $\begin{array}{l}\text { SECPH with IVH } \\
\text { Petechiae in centrum semiovale, } \\
\text { Cerebellar hemorrhage }\end{array}$ \\
\hline 2 & A & DM & $\mathbf{M}$ & 27 & & $\bar{M}$ & $t$ & SB & Bilateral SECPH with IVH \\
\hline 3 & $\bar{B}$ & $\overline{D D}$ & $\mathrm{D}$ & 27 & & $\mathbf{M}$ & & ld & \\
\hline 4 & B & DM & $\mathbf{M}$ & 27 & & $\mathbf{M}$ & & $51 / 2 \mathrm{mo}$. & $\begin{array}{l}\text { Old SECPH with IVH } \\
\text { arachnoiditis and hydrocephalus, } \\
\text { Old, cavitated infarct centrum semiovale } \\
\text { Cerebellar sclerosis }\end{array}$ \\
\hline 5 & B & $?$ & $?$ & 30 & & $\mathbf{M}$ & & $30 \mathrm{~d}$ & $\begin{array}{l}\text { Organized thrombus, superior sagittal sinus } \\
\text { SECPH }\end{array}$ \\
\hline 6 & A & $?$ & $\mathbf{M}$ & 32 & $\bar{d}$ & $\mathrm{~F}$ & & $3 \mathrm{~d}$ & $\begin{array}{l}\text { SECPH } \\
\text { Gliosis of centrum semiovale }\end{array}$ \\
\hline 7 & B & $?$ & $?$ & 32 & & $\mathbf{M}$ & & $5 w$ & $\begin{array}{l}\text { Old cavitated SECPH with IVH } \\
\text { Old hemorrhage \& astrocytosis dentate nucleus } \\
\text { Neuronal loss \& gliosis inferior olive \& } \\
\text { pontine nuclei }\end{array}$ \\
\hline 8 & A & $?$ & $?$ & 34 & & $\mathbf{M}$ & & $15 \mathrm{~d}$ & $\begin{array}{l}\text { SECPH, PVI } \\
\text { Anoxic neuronal necrosis cortex } \\
\text { basal ganglia, thalamus } \\
\text { pontine nuclei, substantia nigra } \\
\text { Purkinje cells } \\
\end{array}$ \\
\hline 9 & $\mathrm{~A}$ & $\overline{D M}$ & $\mathbf{M}$ & $\begin{array}{l}20- \\
22\end{array}$ & d & M & & $1 \mathrm{~min}$. & $\begin{array}{l}\text { Body weight } 240 \text { gms. Brain weight } 60 \text { gms } \\
\text { SECPH, petechiae right frontal cortex }\end{array}$ \\
\hline 9 & B & DM & $\mathbf{M}$ & & $r$ & $\mathrm{M}$ & & $37 \mathrm{~min}$. & $\begin{array}{l}\text { SECPH } \\
\text { Body weight } 340 \text { gms. Brain weight } 50 \text { gms }\end{array}$ \\
\hline 10 & A & & $\mathbf{M}$ & $\begin{array}{l}20- \\
22\end{array}$ & & $\mathrm{~F}$ & & SB & $\begin{array}{l}\text { Acardiac monster - } \\
\text { Bilateral infarcts with macrophages \& } \\
\text { cavitation } \\
\text { Probably occurred } 7-10 \text { days prior } \\
\text { to delivery } \\
\end{array}$ \\
\hline 10 & $\mathrm{~B}$ & & $\mathrm{M}$ & & & $F$ & & $10 \mathrm{~min}$. & \\
\hline 11 & A & $\mathrm{DD}$ & $?$ & 24 & & $\mathbf{M}$ & & $7 \mathrm{~h}$ & $\begin{array}{l}\text { Hemorrhage in choroid plexus } \\
\text { Body wt } 450 \text { gms. Brain wt } 75 \text { gms }\end{array}$ \\
\hline 11 & $\mathrm{~B}$ & DD & $?$ & & & $\mathbf{M}$ & & $9 \mathrm{~h}$ & Body wt 650 gms. Brain wt 90 gms \\
\hline 12 & $\bar{A}$ & DM & $\bar{M}$ & 27 & & $\mathbf{M}$ & + & $1 \mathrm{~d}$ & $\begin{array}{l}\text { Body wt } 660 \mathrm{gms} \text { at birth. } \\
\text { SECPH with IVH }\end{array}$ \\
\hline 12 & $\mathrm{~B}$ & $\mathrm{DM}$ & $\mathbf{M}$ & & & $\mathbf{M}$ & & $17 \mathrm{~d}$ & $\begin{array}{l}\text { Body wt } 990 \text { gms at birth. SECPH } \\
\text { Extensive PVI. Infarct of putamen \& right } \\
\text { tempero-occipital region }\end{array}$ \\
\hline 13 & $\begin{array}{l}\text { A } \\
\text { B }\end{array}$ & & $\begin{array}{l}\mathrm{M} \\
\mathrm{M}\end{array}$ & 35 & & $\begin{array}{l}F \\
F\end{array}$ & & $5 \mathrm{~min}$. & $\begin{array}{l}\text { Conjoined dicephalus } \\
\text { )tripus tribrachius } \\
\text { )Brain weights A: } 210, \mathrm{~B}: 350 \mathrm{gms}\end{array}$ \\
\hline
\end{tabular}

A first born

B second born

DM diamniotic monochorionic

DD diamniotic dichorionic

M monozygous

D dizygous donor, twin transfusion

$r$ recipient twin transfusion

F female

M male

IUGR intrauterine growth retardation

+ present
$1-8$

9-13 both twins autopsied

SECPH subependymal cell plate hemorrhage

PVI periventricular infarction 


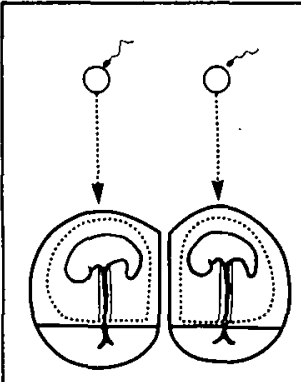

$\mathrm{DZ}$

DD

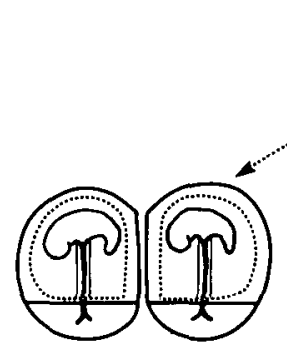

DD

$33 \%$

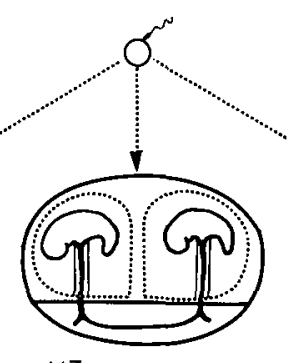

$M Z$

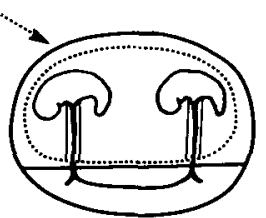

$\mathrm{DM}$

$61 \%$
$M M$

$6 \%$

......... amnion

- chorion

Figure I - Diamniotic dichorionic dizygous twins on left. Placenta can be fused or separate. The three on the right are monozygous twins. DD: diamniotic dichorionic. DM: diamniotic monochorionic. MM: monoamniotic monochorionic. Vascular anastomoses occur in $90 \%$ of all monochorionic placentas.

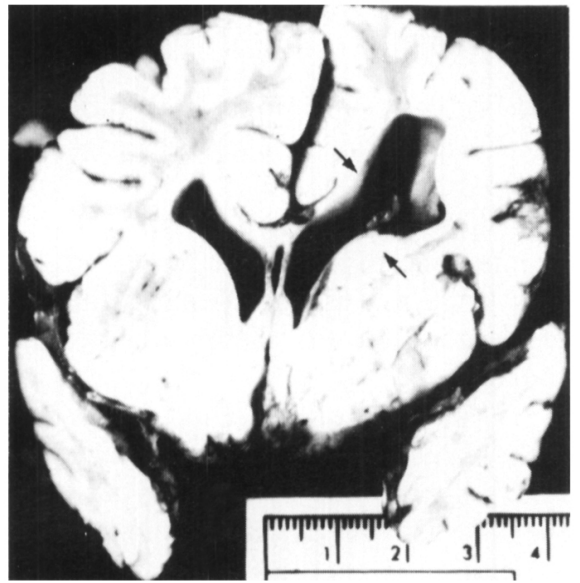

Figure 2 - Case 4: Infant had a subependy mal cell plate hemorrhage which extended into ventricles. Subsequently hydrocephalus was treated by ventriculostomy. The cavitated area in the right centrum semiovale is interpreted as an old area of periventricular infarction occurring in addition to the SECPH. Infant lived to $51 / 2$ months with many complications of prematurity.

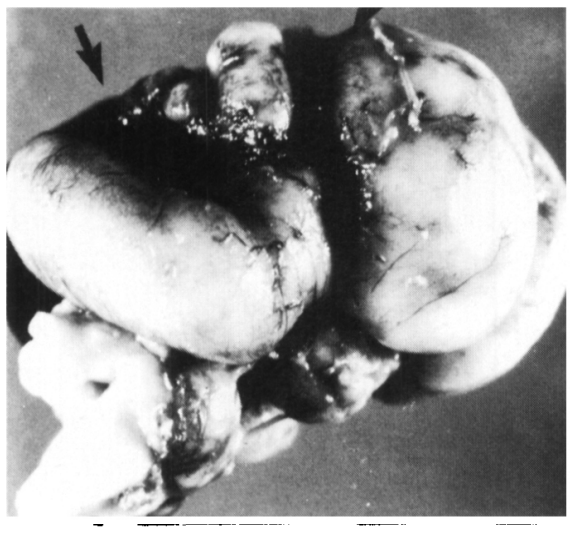

Figure 3 - Case 10

A. Lateral view. Irregular area in right middle cerebral artery territory is an infarct.
PVI and other infarcts of the brain. Case 10A was a stillborn acardiac 7-10 day old infarctions in the middle cerebral artery territory. The other twin of this pair, had a normal brain (Fig. 3 A, B). The fourth pair (13 A, B) consisted of conjoined dicephalus tripus tribrachius thoracopagus twins of 35 weeks gestation whose brains weighed 210 and 250 grams respectively. Cases $11 \mathrm{~A}$ and $\mathrm{B}$ were diamniotic dichorionic twins of unknown zygosity whose body weights were 450 and 650 grams and brain weights 75 and 90 grams respectively.

\section{DISCUSSION}

\section{Mortality and morbidity}

This paper describes lesions in 18 liveborn and stillborn twins whose brains could be examined. Perinatal mortality is $8-12 \%$ in twin pregnanfetus with extensive bilateral cavitated,

cies, (Editorial, British Medical Journal, 1977), a mortality eight times higher in multiple births than singletons (Leetz, 1976). If fetal mortality is included, the death rate is $17 \%(\mathrm{My}$ rianthopoulos, 1970). Medearis et al (1979) found $1 \%$ of pregnancies were twins, but these accounted for $10.1 \%$ of neonatal deaths, and complications before labour occurred in $21.2 \%$ of twin pregnancies. The mortality of monozygotic (MZ) twins is higher than dizygotic (DZ). $23.5 \%$ of twins are small for gestational age ( $\mathrm{Ho}$ and $\mathrm{Wu}$, 1975), and several reports indicate that prematurity, degree of maturity or low birth weight are the determining factors in a twin's fate (Kauppila et al, 1975; Pettersson et al, 1976; Chandra and Harilal, 1978; Záhalková, 1978; Medearis et al, 1979). In an institution for the mentally retarded, $6.8 \%$ of the population with "cerebral palsy" were twins, a greater incidence of twins than in the normal population (Durkin et al, 1976).

Although this series is too small to deduce hazards due to birth order, several authors point out that the second born suffers more asphyxia than the first. Koivisto et al (1975) reports the second twin had lower Apgar scores and was more often referred to the special nursery than the first. They speculate that the circulation to the placenta deteriorates after the birth of the first twin, resulting in more birth asphyxia in the second. Ho and W.u (1975) report that the number of second twins with an Apgar of less than 7 was significantly greater than the first. Müller-Holve et al (1976) found that

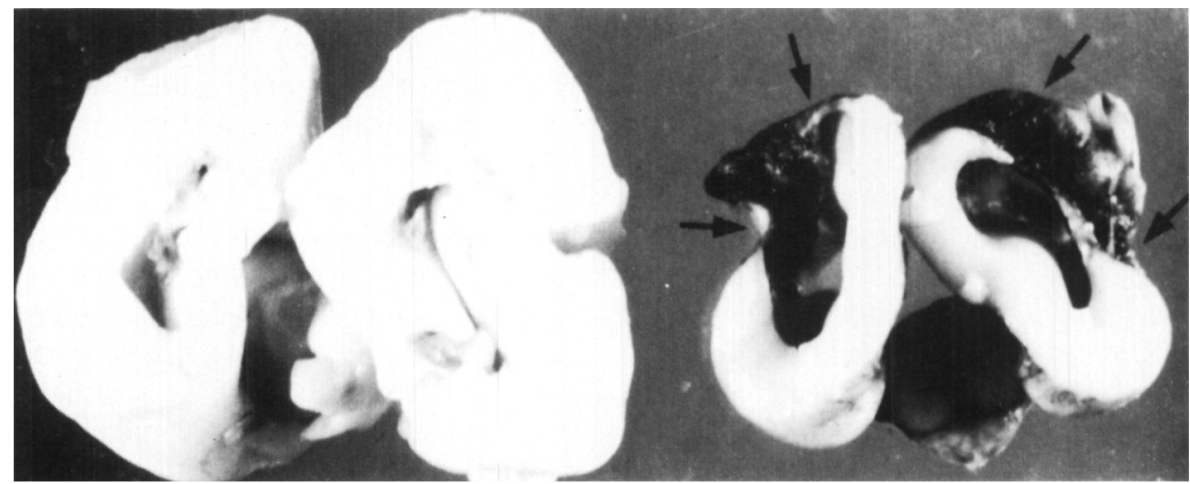

3B. Coronal sections, level of posterior horns. Brain of good twin on left, acardiac monster on right. Note brain on right is smaller, contains more or less symmetrical infarcts. 
the $\mathrm{pH}$ value in the umbilical artery blood of the second twin decreased with increased time after delivery of the first.

\section{Subependymal cell plate hemorrhage}

SECPH was present in 11 of these infants, and had ruptured into the ventricles in 5. SECPH has been reviewed recently (Norman, 1978; Pape and Wigglesworth, 1979; Hill and Volpe, 1981). Since it is a lesion of prematurity, predictably it was the commonest lesion found in this series since all infants were premature. These hemorrhages are present in up to 80$90 \%$ of necropsies on prematures, and since the advent of computed tomography and diagnostic ultrasound they are known to occur in approximately $40 \%$ of survivors of intensive care nurseries (Lazzarra et al, 1980; Papile et al, 1978).

\section{Periventricular infarction}

PVI, also known as periventricular leukomalacia, (Banker and Larroche, 1962) was the next most common lesion $(4 / 18)$. These lesions are probably due to failure of perfusion due to hypotension (Norman, 1978), perhaps in a vulnerable focus (Rice et al, 1978). They can result in mental retardation and spastic hemiplegia (DeRueck et al, 1972; Armstrong and Norman, 1974).

\section{Anoxic lesions}

Anoxic neuronal damage was seen in three infants. Antenatal factors such as overdistension of the uterus with decreased blood flow (Leroy, 1976; Power, 1973) and decrease in uterine blood flow in hypertensive disease of pregnancy, which occurs in $21 \%$ of twin pregnancy as against $8 \%$ of all pregnancies (Ho and $\mathrm{Wu}, 1975$ ), may operate to decrease fetal oxygenation. Anoxic episodes can occur during or after delivery. Hypoglycemia, present in $10 \%$ of twins, (Ho and $\mathrm{Wu}, 1975$ ) may also produce neuronal damage.

\section{Cavitated and destructive lesions}

One infant was an acardiac fetus in whom extensive antenatal cerebral infarction had occurred (Fig. 3). Thrombi were absent in cerebral vessels. The infarction was attributed to reversal of flow through artery-to-artery and vein- to-vein anastamoses in the placenta (Kaplan and Benirschke, 1979), and the fact that the brain of the fetus was supplied by the heart of the normal twin, a situation unique to acardiac monsters. Although the acardiac fetus is rare, twins generally are more prone to develop cavitated cerebral lesions than singletons. The terms "Multicystic encephalomalacia", "porencephaly" and "hydranencephaly" denote these areas of necrosis and cavitation in infants' brains, but imply nothing of the etiology. Friede (1975), Ferrer and $\mathrm{Na}$ varro (1978), and Smith and Rodeck (1975) all attribute these cavitated lesions to circulatory problems. Benirschke (1961) reported a case of a live born twin with fibrin thrombi and cerebral infarcts and suggested that the thrombi were due to release of thromboplastins from the macerated stillborn fetus through the monochorionic placenta to the live twin who suffered disseminated intravascular coagulation (DIC).

Cardiovascular collapse alone can produce DIC in neonates (Zipursky et al, 1978) and such collapse can be produced by abruptio placenta, placenta praevia, other cord or placental catastrophes, and presumably by circulatory inequalities between twins in monochorionic placentas, $90 \%$ of which have vascular anastamoses. Cardiovascular collapse alone can explain some infarcts in infants' brains and the same collapse could produce DIC and fibrin thrombi. This theory covers both singletons and twins. It does not exclude the possibility of the circulating thromboplastins from a macerated twin postulated by Benirschke (1961), but never demonstrated. Hoyme et al (1981) add sludging, hypovolemia and anemia to the list of possible mechanisms for brain damage in monochorionic twins, and point out that when a lesion results from a vascular accident, parents can be told the recurrence risk is negligible. Twins may also have noncavitated destructive cortical lesions, presumably due to perfusion problems occurring as a result of vascular anastamoses in monochorionic placentas (Norman, 1980) or "placental insufficiency" (Caviness, 1979).

\section{Difference in brain size}

One pair of conjoined twins was present in this series. The brain weight of Twin A was $60 \%$ that of the other twin. The difference in size may be due to unequal cleavage, but is more likely due to differences in growth resulting from unequal cerebral blood supply. These twins had a common liver with a severely malformed heart in twin A and normal heart in twin B. It is likely that the difference in brain size is due to a lesser blood supply to the brain in twin A than twin B. The cephalothoracopagus janiceps described by Slager, et al (1981) showed asymmetry of the two fused brains with necrosis in one which the authors attribute to chronic ischemia on that side resulting from anomalies of the blood vessels supplying the head.

Two pairs of twins had different sized bodies and brains. In cases $9 \mathrm{~A}$ and $9 \mathrm{~B}$ the difference in body weight was due to the twin transfusion syndrome. The difference in brain weight was small and its significance difficult to assess because there was hemorrhage in both brains. The other pair (11A and 11B) of like sexed diamniotic dichorionic twins of unknown zygosity had unequal body and brain sizes. If they were dizygous this inequality may indicate difference in genetic structure but could also be due to difference in placentation and intrauterine environment. Although genetic differences in monozygous twins theoretically can result from difference in cytoplasmic inheritance, a post-zygotic new mutation (Nance, 1979) or post-zygotic nondysjunction in one individual (Carakushansky and Berthier, 1976), the difference in the brains of a monozygous twin pair is most probably acquired in utero due either to twin transfusion syndrome or inequalities of placentation. Twin transfusion occurs in monochorionic placentas. The shared circulation may be in equilibrium, strongly imbalanced with severe transfusion and intrauterine death of one twin, or moderately unbalanced with both twins born living, in which case $20 \%$ survive (Rausen et al, 1966). Extreme imbalance of circulation results in an acardiac monster with large artery to artery and vein to vein 
anastamoses (Leroy, 1976; Barghava and Chakravarty, 1975; Kaplan and Benirschke, 1979). Morphometric examination of brains in chronic TTS has shown the donor twin to have a smaller brain (Naeye, 1965) and a measured reduction of cytoplasmic mass (Benirschke and Kim, 1973). Corey, et al (1979) suggest that the relative position of twins to placentae may have more influence on variation in birth weight than does the presence or absence of vascular anastamoses.

\section{Intelligence}

The study of monozygous twins reared apart has been regarded as a model to help differentiate the effect of genes and environment on intelligence. This model assumes that brains of monozygous twins are identical at birth. We know nothing of the morphological, physiological and chemical substrate of intelligence, nor what cellular events occur during intrauterine development which determine intelligence. Although these events are highly programmed, nothing guarantees that they are identical in monozygous twins. Even uncomplicated twin pregnancies are associated with high perinatal mortality and morbidity. Twins surviving the hazards of intrauterine competition, or even a shared circulation, may have experienced intrauterine and subsequent perinatal events which could affect equality of brain function later, without producing overt signs of neurological deficit at birth. Price $(1950,1978)$ pointed out that the difference in the environment of twins begins not at birth, but months before when the twins are formed.

\section{REFERENCES}

ARMSTRONG, D., NORMAN, M.G., (1974) Periventricular leukomalacia in neonates: complications and sequelae. Arch. Dis. Child. 49, 367-375.

BANKER, B.Q., LARROCHE, J.C. (1962) Periventricular leukomalacia of infancy. Arch. Neurol. 7, 32-56.

BARGHAVA, I., CHAKRAVARTY, A. (1975) Vascular anastamoses in twin placentae and their recognition. Acta Anat. 93, 471-480.
BENIRSCHKE, K. (1961) Twin placenta in perinatal mortality. N.Y. State J. Med. 61, 1499-1508.

BENIRSCHKE, K., KIM, C.K. (1973) Multiple pregnancy. N. Engl. J. Med. 288, 12761284.

CARAKUSHANSKY, G., BERTHIER, C. (1976) The de Lange syndrome in one of twins. J. Med. Genet. 13, 404-406.

CAVINESS, V.S. Jr., EVRARD, P., LYON, G. (1978) Radial neuronal assemblies, ectopia and necrosis of developing cortex: a case analysis. Acta Neuropathol. 41, 67-79.

CHANDRA, P., HARILAL, K.T. (1978) Pleural births mortality and morbidity. Prog. Clin. Biol. Res. 24B, 109-114.

COREY, L.A., NANCE, W.E., KANG, K.W., CHRISTIAN, J.C. (1979) Effects of type of placentation on birthweight and its variability in monozygotic and dizygotic twins. Acta Geneticae Medicae et Gemellologiae, 28, 44-50.

DeRUECK, J., CHATTA, A.S., RICHARDSON, E.P. Jr. (1972) Pathogenesis and evolution of periventricular leukomalacia in infancy. Arch. Neurol. 27: 229-236.

DURKIN, M.V., KAVEGGIA, E.G., PENDLETON, E., NEUHAÜSER, G., OPITZ, J.M. (1976) Analysis of etiologic factors in cerebral palsy with severe mental retardation. Eur. J. Pediatr. 123, 67-81.

Editorial, Br. Med. J. (1977) Preventing prematurity in twins. $1,1618$.

FERRER, I., NAVARRO, C. (1978) Multicystic encephalomalacia of infancy. J. Neurol. Sci. 38, 179-189.

FRIEDE, R.L. (1975) Developmental Neuropathology. New York, Vienna, SpringerVerlag, pp. 102-122.

HILL, A., VOLPE, J.J. (1981) Seizures, hypoxic-ischemic brain injury and intraventricular hemorrhage in the newborn. Ann. Neurol. 10: 109-121.

HO, S.K., WU, P.Y.K. (1975) Perinatal factors and neonatal morbidity in twin pregnancy. Am. J. Obstet. Gynecol. 122, 979-987.

HOYME, H.E., HIGGINBOTTOM, M.C., JONES, K.L. (1981) Vascular etiology of disruptive structural defects in monozygotic twins. Pediatrics 67, 288-291.

KAPLAN, C., BENIRSCHKE, K. (1979) The acardiac anomaly: New case reports and current status. Acta Geneticae Medicae Gemellol. 28: 51-59.

KAUPPILA, A., JOUPPILlA, P., KOIVISTO, M., MOILANEN, I., YLIKORKALA, O. (1975) Twin pregnancy: a clinical study of 335 cases. Acta. Obstet. Gynecol. Scand. (Suppl.) 44, 5-12.
KOIVISTO, M., JOUPPILA, P., KAUPPILA, A., MOILANEN, I., YLIKORKALA, $O$. (1975) Twin pregnancy: Neonatal morbidity and mortality. Acta. Obstet. Gynecol. Scand. (Suppl.) 44, 21-29.

LAZZARRA, A., AHMANN, P., DYKES, F., BRANN, A.W. Jr., SCHWARTZ, J. (1980) Clinical predictability of intraventricular hemorrhage in preterm infants. Pediatrics, $65,30-34$.

LEETZ, I. (1976) Twin pregnancy as a high risk pregnancy. Acta Genet. Med. Gemellog. $25,307-310$.

LEROY, F. (1976) Major fetal hazards in multiple pregnancy. Acta. Genet. Med. Gemellol., 25, 299-306.

MEDEARIS, A.L., JONAS, H.S., STOCKBAUER, J.W., DOMKE, H.R. (1979) Perinatal deaths in twin pregnancy. Am. J. Obstet. Gynecol. 134, 413-4I8.

MÜLLER-HOLVE, W., SALING, E., SCHWARZ, M. (1976) The significance of the time interval in twin delivery. J. Perinat. Med. 4, 100-105.

MYRIANTHOPOULOS, N.C. (1970) An epidemiological survey of twins in a large, prospectively studied population. Am. J. Hum. Genet. 22, 611-629.

NAEYE, R.L. (1965) Organ abnormalities in a human parabiotic syndrome. Am. J. Pathol. 46, 829-842.

NANCE, W.E. (1979) The role of twin studies in human quantitative genetics. Prog. Med. Genet. 3, 73-107.

NORMAN, M.G. (1978) Perinatal brain damage. Perspect. Pediatr. Pathol. 4, 41-92.

NORMAN, M.G. (1980) Bilateral encephaloclastic lesions in a 26 week gestation fetus: effect on neuroblast migration. Can. J. Neurol. Sci. 7, 191-194.

PAPE, K.E., WIGGLESWORTH, J.S. (1979) Hemorrhage, ischemia and the perinatal birth. Clinics in Developmental Medicine $69 / 70$, London, William Heinemann Medical Books, pp. 133-148.

PAPILE, L.A., BURSTEIN, J., BURSTEIN, R., KOFFLER, H. (1978) Incidence and evolution of subependymal hemorrhage: a study of infants with birth weights less than $1500 \mathrm{Gm}$. J. Pediatr. 92, 529-534.

PETTERSSON, F., SMEDBY, B., LINDMARK, G. (1976) Outcome of twin birth. Acta Paediatr. Scand. 65, 473-479.

POWER, W.F. (1973) Twin Pregnancy: Complication and treatment. Obstet. Gynecol. 42, 795-808.

PRICE, B. (1950) Primary biases in twin studies, a review of prenatal and natal difference-producing factors in monozygotic pairs. Am. J. Hum. Genet. 2, 293-352. 
PRICE, B. (1978) Bibliography on prenatal and natal influences in twins. Acta Genet. Med. Gemellog. 27, 97-113.

RAUSEN, A.R., SEKI, M., STRAUSS, L. (1966) Twin transfusion syndrome. J. Ped. 66, 613-628.

RICE, J.E. III, VANNUCCI, R.C. BRIERLEY, J.B. (1981) The influence of immaturity on hypoxic-ischemic brain damage in the rat. Ann. Neurol. 9, 131-141.
SLAGER, U.T., ANDERSON, V.M., HANDMAKER, S.D. (1981) Cephalothoracopagus janiceps malformation: a contribution to the pathogenesis of cerebral malformation. Arch. Neurol. 38, 103-108.

SMITH, J.F., RODECK, C. (1975) Muitiple cystic and focal encephalomalacia in infancy and childhood with brain stem damage. J. Neurol. Sci. 25, 377-388.
ZÁHALKOVA, M. (1978) Perinatal \& infant mortality in twins. Prog. Clin. Biol. Res. 24B, 115-120.

ZIPURSKY, A., deSA, D., HSU, E., JOHNSTON, M., MILNER, R. (1978) Clinical and laboratory diagnosis of hemostatic disorders in newborn infants. Am. J. Pediatr. Hematol. Oncol. 1, 21 7-226. 